\title{
Dyke-like and veined bodies' complex of the Elov deposit (the Northern Urals)
}

\author{
E. Nikolaeva \\ Assist. Prof., Mining university, Saint-Petersburg, Russia \\ I.V. Talovina \\ Prof., Head of the Hystorical and dynamic geology department, Mining university, Saint-Petersburg, \\ Russia \\ G. Heide \\ Prof., Institutsdirektor, Technische Universität Bergakademie Freiberg, Freiberg, Germany
}

\begin{abstract}
The object of study is the Elov deposit, which is located in the Sverdlovsk region (the Northern Urals, Russia). Based on a comprehensive analysis of geological, mineralogical and petrographic data of the dyke-like and veined bodies of the Elov deposit, the patterns of influence of the veined rocks' composition and quality, as well as the distribution of ore mineralization in them has been researched. Further study of this topic will help to expand the region's prospects for the nickel mineralization's exploration.
\end{abstract}

Keywords: Elov deposit, Urals, nickeliferous weathering crust, minor intrusions of gabbros and granitoids, dykes, veined bodies

\section{INTRODUCTION}

The formation of nickel-bearing weathering crusts is the leading geological-industrial type in the world in terms of reserves and mining of nickel. In Russia the main deposits of nickelbearing weathering crusts are located in well-developed mining regions of the Urals and have been forming the raw material base of the cobalt-nickel industry developed in the Urals for many years.

The formation of nickel-bearing hypergenic weathering crusts is spatially confined to ultramafite formations, the bright examples of which are dunite-harzburgite complexes of the ophiolite formation type and dunite-clinopyroxenite massifs of the zonal formation type.

Nickel-bearing weathering crusts and nickel deposits associated with this type' crusts are mainly developed on ophiolite type' harzburgites and dunites, which in the Urals are represented by a considerable number of large, medium and small massifs confined to deep-seated faults and forming a series of meridional ultramafic belts. The formation of nickel-bearing weathering crusts occurs less often on the dunite-clinopyroxenite massifs of the zonal formation type, confined mainly to the Platiniferous Belt of the Urals.

The geological position and structure of many ultrabasic massifs of the Urals are interpreted ambiguously in the scientific literature despite the long period of study. In this regard, more detailed study of both the mineralogical and petrographic composition of the Urals' massifs' rocks is required. 


\section{GEOLOGY}

The Elov deposit is located on the eastern frontier area of the Kola (Serov) massif in that part of it where hyperbasites are on the border of large protrusion of gneiss-shaped diorites, which were classified by I.S. Lisov (1968) among Pre-cambrian (Figure 1).

The deposit has a very complex geological structure, it is composed of hyperbasites serpentinized to varying degrees or completely transformed into serpentinites and penetrated by dykes and dyke-like bodies of various compositions all over. The hyperbasites presented dunites, peridotites and pyroxenites. Peridotites are the predominant rocks. Dunites are spread less and often interspersed with peridotites. Pyroxenites are found in the eastern part of the deposit mainly, where they fringe the Kola (Serov) massif in the form of wide (100$300 \mathrm{~m}$ ) ribbon in contact with the Pre-cambrian gneiss-like diorites and granitoids.

Also pyroxenites were found in the southwestern part of the deposit among apoperidotite serpentinites in the form of bodies with thickness of up to 8-10 m.

In the northwestern part of the deposit the hyperbasites are on the border of diorites fresher in age, also numerous apophyses and dykes fall back into hyperbasites. These bodies have submeridional strike and steep mostly eastern pitch, their thickness of up to several tens of meters is.

In addition to the aforementioned dikes and apophyses there is a large number of weathered vein-like bodies having different compositions, a wide variety of shapes, differing thicknesses and various dips and strikes in the weathering crust of hyperbasites.

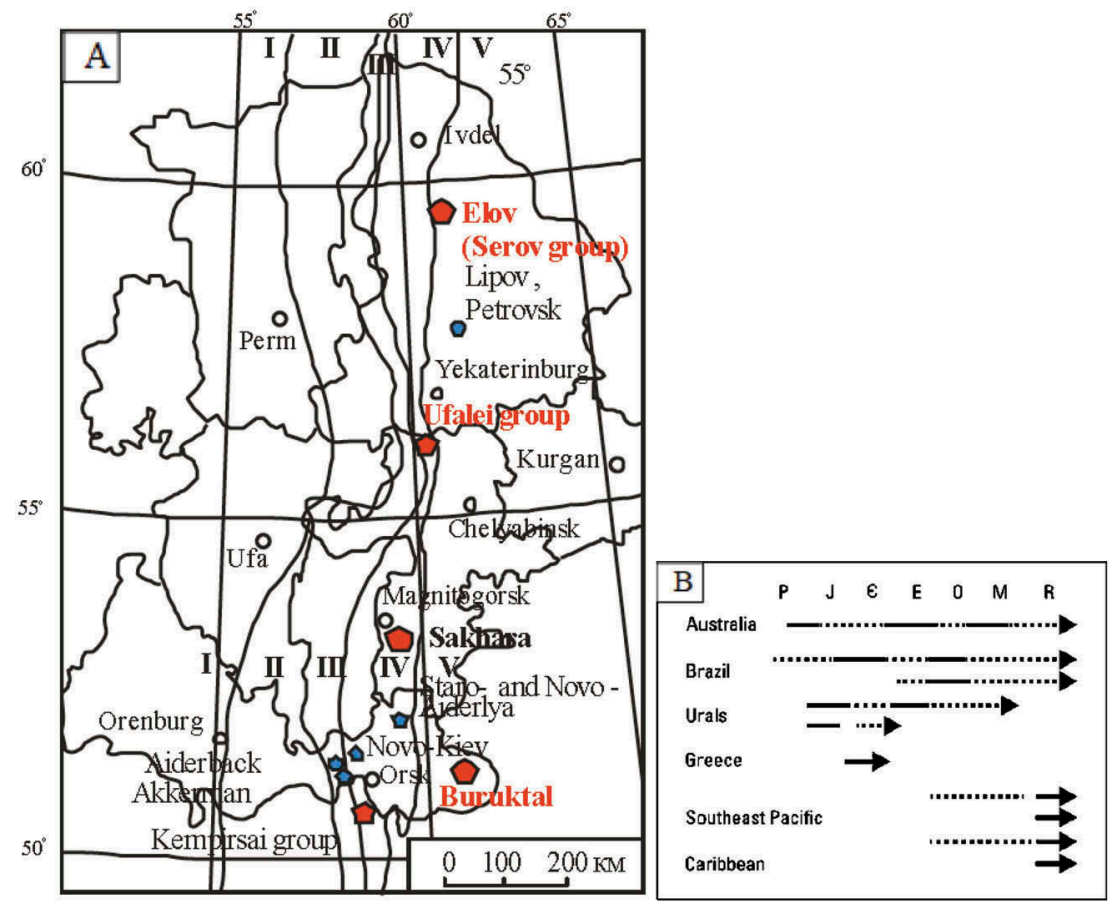

Figure 1. (A) Main tectonical units of the central and northern Urals with the nickelhydrosilicate ore deposits (after Mikhailov, 2002) and (B) Periods of nickel laterite formation in various provinces (after Marsh et al., 2013).

Tectonic zones: I, the East-European platform; II, the Fore-Ural megazone; III, the Central-Ural megazone; IV, the Tagil-Magnitogorsk megazone; V, the East-Ural megazone. Main supergene nickel deposits: the Buruktal deposit, the Ufalei group (the Cheremshanka, the Sinara, the Rogozha deposits), the Serov group (the Elov deposit). P, Paleozoic, J, Jurassic, C, Cretaceous, E, Eocene, O, Oligocene, M, Miocene, R, Recent. 
According to exploratory drilling's and mining works' data loose weathering products of vein-rocks in weathered hyperbasites are found in the upper part of the geological record much more often than vein-shaped bodies in fresh hyperbasites at depth.

Considering the data of measurements of dip and strike of vein-shaped bodies in prospect holes and cut acrosses, we can conclude that the vein-shaped bodies of southwestern strike in the central part of the Elov deposit prevail. The vein-shaped bodies of both northwestern and southeastern strike are equally spread. The vein-shaped bodies of northeastern strike are widespread in this area to a much lesser extent. The largest of them resemble "feathers" in shape with steeply going down "trunks". In the southern part of the deposit, the vein-shaped bodies are spread much less, the strike is mainly northwestern and southwestern, the pitch is steep.

In the east of the Elov deposit the shallow dipping apophyses of diorites are widespread and they form the lower parts of the geological record.

Nickel-bearing ore mineralization of the Elov deposit (Figure 2) is confined to the weathering crust of ultramafic rocks of peridotite's formation which all nickel deposits of the Urals and the North Kazakhstan are related with.

The Elov deposit (Figure 3) contains a large number of minor intrusions in contrast with all other Urals' deposits and for the formation of the weathering crust with equivalent nickel content as in other deposits with similar composition it could be required twice the amount of nickel in the source serpentinites or double expansion of decayed and weathered serpentinites, from which fully leached nickel was redeposited in orebodies.

According to calculations of the ratio of minor intrusions height to the seam height of serpentinites in the central part of the Elov deposit minor intrusions estimated $40 \%$ of total

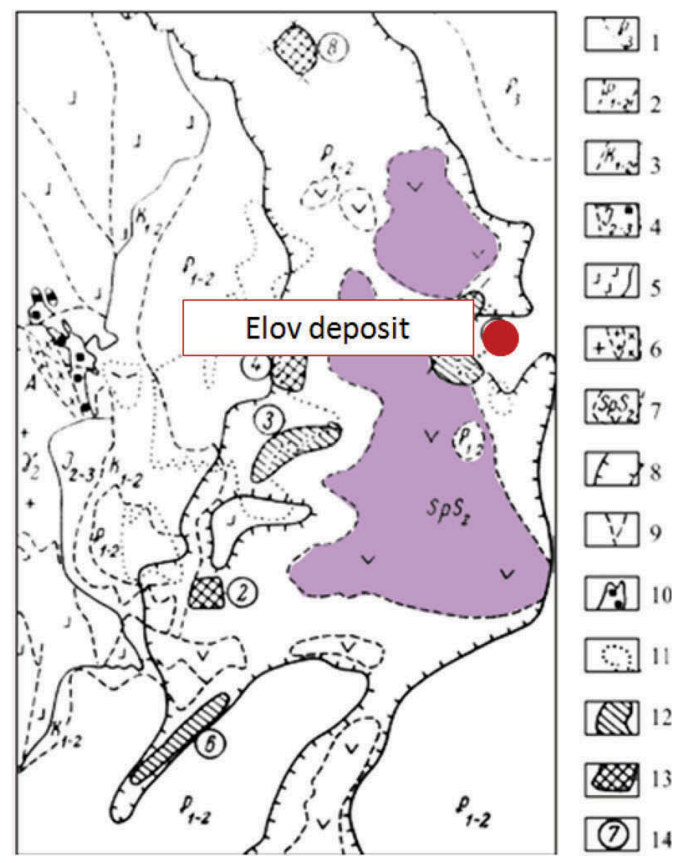

Figure 2. Schematic geological and technological map of deposits of the Serov group (after Vershinin et al., 1988).

1-4, Meso-Cenozoic deposits of the weathering crust; 5-6, Paleozoic formations; 7, day stones of serpentinites; 8, contours of serpentinites in accordance with magnetic survey and drilling; 9 , zones of tectonic dislocations; 10, chalcopyrite-magnetite skarns; 11, nodular-conglomerate sedimentary iron ores in the deposits of the Myssov suite; 12-14, deposits of supergene nickel ores of various technological types: 12, ores for alkaline hydrometallurgical process, 13 , ores for blast smelting process; 14, numbers of deposits. The Serov group of deposits: 7, Elov; 6, Katasmin; 8, Ustey; 2-4, others. 


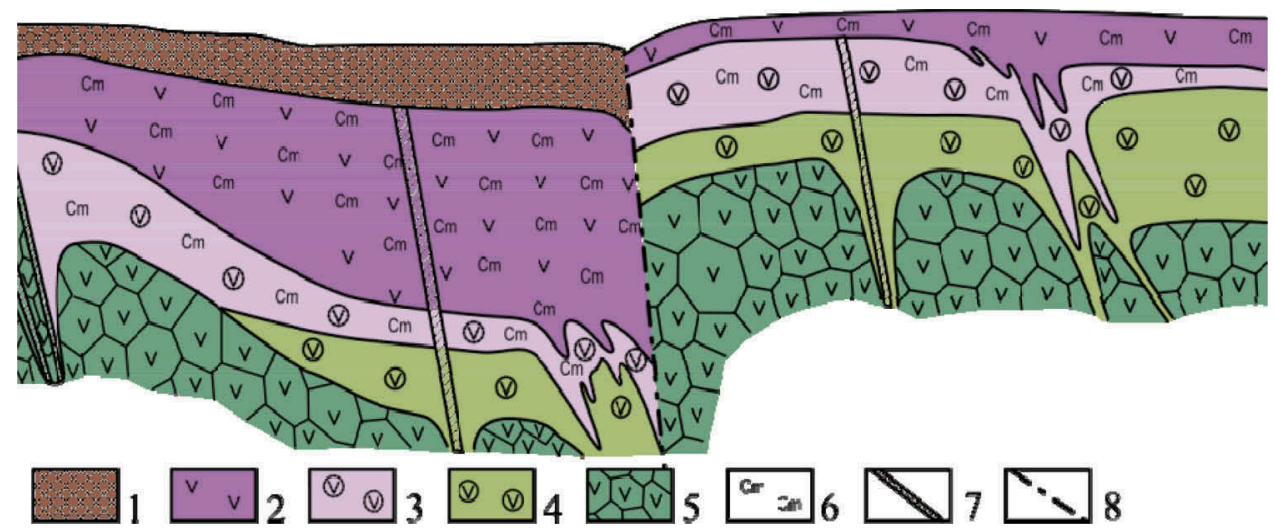

Figure 3. Geological record of the weathering crust of the Elov deposit (after Berkhin et al., 1970). 1 , nodular-conglomerate sedimentary iron ores $\left(\mathrm{K}_{1}\right) ; 2$, nontronited serpentinites; 3 , leached serpentinites; 4, disintegrated serpentinites; 5 , unaltered serpentinites; 6 , chamosites; 7 , chlorite vein-rock; 8 , fractures.

rocks thickness, sometimes in some small areas volume of vein-shaped bodies exceeds volume of the serpentinites.

\section{COMPOSITION AND STRUCTURE}

The composition of the vein-shaped bodies is different. Among them pyroxenites, gabbros, gabbro-porphyrites, odinites, spessartites, diorites and granitoids are noted. One part of the vein-shaped bodies is associated with hyperbasites, and the other part of them refers to granitoids derivatives. Some vein-shaped bodies may have a local contact-reaction-metasomatic genesis, i.e. they are the result of exposure to hyperbasites of post-magmatic liquids associated with granitoids.

The vein-shaped bodies of local contact-reaction-metasomatic genesis have a mutable composition, which varies from gabbroids to granitoids, and often a zonal structure. Zonation in most cases is asymmetric. The near-contact parts of the vein-shaped bodies are usually composed of amphibole rocks with relics of pyroxene and have different thicknesses (from a few centimeters to 1-2 meters). The following zones are represented by gabbroids, diorites, and, less commonly, granitoids sequentially to the center. Contacts between marked types can be either gradual or abrupt. Gabbroids in composition and structure resemble issites, hornblende microgabbros or metamorphic norites such as gabbro-amphibolites. They often have a banded structure, and the direction of banding coincides with the direction of contacts of the vein-shaped bodies with the surrounding hyperbasites. Gabbroids are sometimes represented by rocks of the amphibolite type, in which rocks of the diorites' and granitoids' composition are found in the form of vein-like aggregates and splices with tortuous outlines. In the vein rocks, all of the above varieties are not always present, and more often one or two varieties are absent. Amphibole rocks in the form of angular-shaped "detached masses" of up to 5-10 cm in size are observed in the diorite composition rocks. Narrow reaction rims of chlorite, tremolite and talc with a thickness of up to fractions of a meter, rarely up to 1 meter, are found at the contacts of the metasomatic vein bodies with the hyperbasites. Moreover, chlorite is formed mainly due to vein rocks, and tremolite and talc appear due to hyperbasites and serpentinites. The thickness of the contact-reaction rims depends on the thickness of the vein-shaped bodies. A thin biotite rim is occasionally present before the chlorite rim at the contacts of granitoids or quartz diorites with hyperbasites. Hyperbasites in the near-contact zones are transformed into antigorite serpentinites. The thickness of antigorite serpentinites is usually within a few meters. 
When compiling a geological map of the weathering crust of the Elov deposit, some of the many varieties of rocks described above were combined into several types:

1. the group of hyperbasites includes dunites, peridotites and serpentinites;

2. the group of gabbroids includes vein pyroxenites, gabbros, gabbro-porphyrites, amphibole near-contact rocks such as issits, also odinites and other amphibolites;

3 . the group of dioritoids includes diorites, quartz diorites, spessartites, granodiorites, plagiogranites, granites, plagiaplites and albitites.

\section{TECTONICS}

Paleozoic rocks of the deposit reflect traces of intense tectonic activity. Exploration work revealed a large number of joints and fractured zones of both submeridional and sublateral (East-West, EW) directions. Many of the largest tectonic faults, especially those with an EW trending, are controlled on the present surface of the relief by small rivers and narrows, and the largest submeridional faults in the eastern part of the deposit have steep stair-stepping benching towards the Sos'vin depression. The geological map shows mainly tectonic dislocations, renewed by adjustment movements immediately preceding the encrustation stage and later ones occurring in the Meso-Cenozoic period (cf. Ageev et al. 2019).

In Paleozoic age rocks a highly eroded weathering crust is well developed. The maximum crust thickness according to exploratory drilling wells data reaches 85 meters, and the thickness of nickel-bearing crust with industrial nickel contents in individual sections is up to $50 \mathrm{~m}$. It is represented mainly by the lower zones, i.e. the zones of leaching and integration. The weathering crust has been most fully preserved under Meso-Cenozoic deposits, especially along tectonic dislocations and joints, where strongly decomposed clay products and ochres developed after ultrabasic and basic rocks decomposition are also noted along with leached rocks.

Almost all products of ultrabasic rocks' weathering crust are nickel-bearing in the deposit, including the vein rocks under favorable conditions.

Ores associated with weathering products of ultrabasic rocks account for $76 \%$ of their total volume in the deposit. Of these, $18 \%$ are ochres and heavily ocherized leached nontronitized serpentinites. $24 \%$ of the total ore mass is associated with the weathering products of the vein rocks.

Initially, the weathering crust on the deposit had a wider development scale and greater thickness. Its upper clay and ocher products are mostly eroded at present. The erosion crust was eroded several times throughout the subsequent history of the development of the region, as a result of which the crust was almost completely eroded in some areas.

The free-open textured products of the weathering crust were transferred to the lower parts of the ancient relief of the deposit and were deposited at the bottom of lakes and swamps. They were a source of accumulation and formation of iron bean-conglomerate ores.

The Elov deposit is characterized by a shallow bedding of rocks in comparison with a number of other deposits of the Serov orefield.

In the western part of the deposit, the weathering crust directly lies under the Quaternary age deposits at a depth of the first tens of meters. Further east, as hyperbasites sink, the depth of nickel-bearing crust increases, reaching 80 meters. Meso-Cenozoic deposits appear in the geological record, at the base of which are bean-conglomerate ores. Up the geological record, bean-conglomerate ores are replaced by glauconite-quartz sands, mudstones (or argilites), silica gaizes and diatom earth.

\section{PROCESSING}

Currently, three different processes (Figure 4) are used to extract the nickel and cobalt elements from the mined rocks. The Caron process and high-pressure-acid leaching (HPAL) are mainly used for the oxide ore subtypes. For the nickel clay deposits, the HPAL method is also used with priority, whereas for the serpentine subtypes, a pure melting method is preferred. 


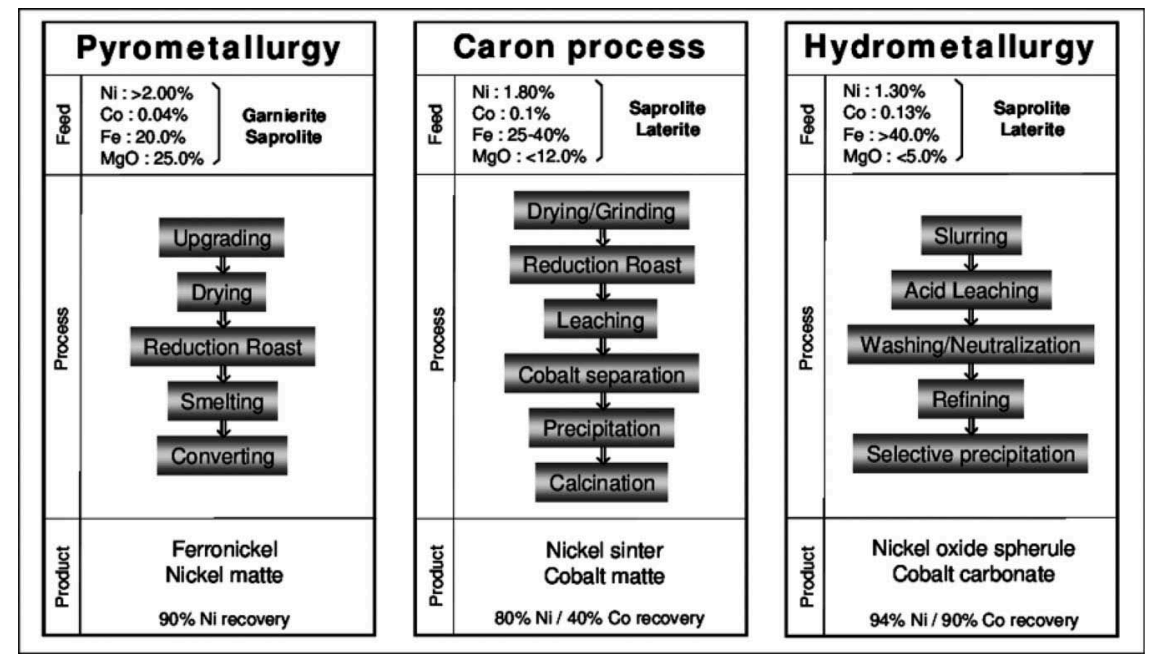

Figure 4. Main processes for the extraction of nickel out of lateritic rocks.

Ongoing research is developing new extraction methods, such as the Dni-Hydrometallurgy process developed by DirectNickel, which can also process the entire laterite profile without prior separation (cf. Kobylyanski et al. 2019). But because of the complexity needed to handle and process the nickel-cobalt laterites, much research has focused on ore delineation and mineralogical identification for distinguishing rocks. Thus it is important to characterize the mineralogy of the Elov deposit in more detail (cf. Lvov et al. 2017).

\section{MATERIALS AND METHODS}

\subsection{Samples}

For the investigation there were nine samples, which were sampled during an excursion by leading of Prof. Dr. Irina Talovina (Saint Petersburg Mining University) and Prof. Dr. Gerhard Heide (TU Bergakademie Freiberg) in the active open pit Elov nearby the town Serov in September 2014. The samples are crude ore as well as country rock that occur within the open pit area. In the following, the samples are listed in Table 1.

\subsection{Analytical methods}

The mineralogical composition of the samples was determined by using x-ray diffraction phase analysis. All samples were prepared as powder preparations. The rocks were crushed

Table 1. The investigated samples with Nickel content, $\%$.

\begin{tabular}{lll}
\hline Sample & Name & $\mathrm{Ni}$ \\
\hline SV 02 & Porphyritic serpentinite & 0.117 \\
SV 04 & Chromite ore & 0.056 \\
SV 06 & Talc-chlorite-schist & 0.542 \\
SV 07 & Limonite ore & 1.160 \\
SV 08 & Gangue rock & 0.199 \\
SV 09 & Contact-zone of SV08 & 0.163 \\
SV 10-1 & Silicate nickel ore & 0.101 \\
SV 10-2 & Silicate nickel ore & 0.979 \\
SV 11 & Oxide nickel ore & 1.030 \\
\hline
\end{tabular}


with a hammer down to a grain size $<400 \mu \mathrm{m}$. The bulk samples were subsequently divided using quarter cross. Further crushing was done using the ball mill XRD-Mill McCrone with $\mathrm{ZrO} 2$-grinding bodies. Technical ethanol $(96 \%)$ was used for cooling and to guarantee careful grinding. After drying, the samples were homogenized by means of an Ardenne vibrator and finally sieved with a $200 \mu \mathrm{m}$ sieve into an aluminum cuvette using the side-loading procedure. The measurements were executed with URD 6 (Mineralogical laboratory TU Bergakademie Freiberg) with Co-radiation.

To investigate the swelling capable minerals which show mainly wide reflexes in the $14 \AA$ area, texture preparations were produced in the traditional way. The selected samples were first measured in an air-dried state, afterwards they were saturated in ethylene glycol vapor and then measured again. The ethylene glycol accumulates in the interlayers of the minerals and causes a widening of the structure, thereby increases the layer distance. After the second measurement, all texture preparations were annealed at $400{ }^{\circ} \mathrm{C}$ and measured again. The last measurement was executed after an annealing process at $550{ }^{\circ} \mathrm{C}$.

Thermal analyses were carried out in the mineralogical laboratory of the TU Bergakademie Freiberg by Dipl.-Chem. Margitta Hengst. All measurements were realized by means of the STA 409 PC, and a heating rate of 10 kelvin per minute, up to a maximum temperature of $1200{ }^{\circ} \mathrm{C}$. As carrier gas, purified air was used for all analyses. The reference material for the DTA analyses was corundum (cf. Földvari 2011).

The observations on the scanning electron microscope (SEM) were mainly examined on polished thin sections of the solid rocks. Individual measurements were also carried out on strewn slides. For the investigations it was possible to use the CarryScope JCM-5700 from the museum "Terra Mineralia Freiberg". This SEM is equipped with a Bruker EDX (133eV). The focus of this analytical method was the determination of the spinel group minerals. Further questions arose with regard to the distribution of the various valuable elements inside the rock units, primarily nickel. As far as possible, this method allowed the investigation of the local coupling of nickel to the various minerals.

\subsection{Results}

The chemical analyses show a significant accumulation of nickel in various rocks of the open pit. Most of the silicate dominated areas of the deposit contain higher nickel concentrations, however, they are not high enough to reach economic relevance. The rocks display nickel contents between $0.101 \%$ and $0.542 \%$. An exception is the major amount of silicate nickel ore (SV $10-2$ ), which at $0.979 \%$ shows significantly increased nickel contents of economic importance. It is note-worthy that only the unaltered areas of the silicate nickel ore have significantly elevated contents, while the secondary silicified zone has only a very low nickel content of $0.101 \%$. Since the biggest difference lies in the mineral composition, in this case the increased content of serpentine and especially smectite in the non-silicified areas, the nickel must be linked to exactly these minerals. It can be assumed that these are typical nickel-containing nontronites (cf. Brindley 1984b, Brindley et al. 1973).

The highest nickel contents were detected in the oxidic type nickel ore of SV $11(1.03 \%)$ and in the limonite ore of SV $07(1.16 \%)$. Thus, these areas are most enriched when considering the absolute contents. As far as the limonite ore is concerned, it can be assumed that the nickel is primarily coupled to nickel-rich goethite and very occasionally to nickel sulphides. The rock contains neither smectite nor talc, and the serpentine branch veins (apophysis) in which EDX analyses did not show any major nickel content, are the result of later secondary formation. According to the elevated position of the dehydroxilation peak, the thermal analyses of goethite indicate a significant foreign metal substitution, further substantiating the thesis of nickel-rich goethite (cf. Talovina 2012, Talovina et al. 2008, 2010, 2011, 2012). Although nickel sulphides have been detected in limonite ore, their absolute contents are negligible compared to the substitutional placement in the goethite structure. This is corroborated by the missing peaks in the powder diffraction pattern as well as by the low sulphur content of the sample. It merely amounts to $0.10 \%$ sulphur content compared to the $1.16 \%$ nickel content. In the oxidic type nickel ore (SV 11), the nickel carrier cannot be reliably determined. 
However, enrichment in the silicate components seems to be plausible, especially in chlorite and smectite as well as in goethite, which also has increased d values. Also in this particular rock the serpentines showed no relevant nickel content throughout the EDX measurements.

\section{CONCLUSION}

The Serov group of deposits is one of the sedimentary-infiltration formations. The OrskKhalilovsk, Aydyrlinsk and other deposits, except the Elov deposit, belong to this kind of formations in the Urals. In this type a significant role belongs to the nickel-containing ore-forming ferruginous chlorite, i.e. shamosite $(\mathrm{Fe} 5 \mathrm{Al})(\mathrm{AlSi3O})(\mathrm{OH}) 8$. The deposits of this type had experienced a rather complex history of formation, including the stage of epigenesis (destruction, transportation and deposition with the formation of ferrous sedimentary rocks) in addition to the lateritogenesis stage (cf. Yudovich et al. 2011).

The vertical zonal profile in the nickel weathering crust of the Elov deposit is observed (from the bottom up): serpentinized ultramaficites (substrate) - serpentinite zone - nontronite zone - oxide-iron zone. Separately, it is worth noting the shamosite zone, which belongs to the converted part of the weathering crust of the Elov deposit, has a limited distribution and replaces serpentinite, nontronite and oxide-iron zones in part or completely.

The research displays a very diverse mineralogy in the rocks of the Elov deposit. It was shown that different types of rocks from variously weathered areas of the deposit have relevant nickel contents. Due to the different mineralogy of the nickel-bearing minerals between laterite and saprolite, both a selective mining and a selective processing of the individual types of ore should be considered.

\section{ACKNOWLEDGEMENTS}

The work is carried out with financial support of Ministry of Education and Science of Russian Federation according to grant program "Research and development in priority areas of development of Russia's scientific and technical complex for 2014 - 2020", the project RFMEFI61620X0127.

\section{REFERENCES}

Ageev A. S., Ilaliva R. K., Duryagina A. M., Talovina I. V. A link between spatial distribution of the active tectonic dislocation and groundwater water resources in the Baikal-Stanovaya shear zone. Gornyy informatsionno-analiticheskiy byulleten'. 2019;5:173-180. [In Russ]. DOI: 10.25018/0236-14932019-05-0-173-180.

Bugelskiy, J. J., I. V. Vitovskaya, A.P. Nikitina. 1990. Ekzogennye rudoobrazujushhie sistemy kor vyvetrivanija (Exogenic Ore-forming Systems of Weathering Crusts). Moscow, Nauka, 365 p. (in Russian).

Földvari M. 2011. Handbook of thermogravimetric system of minerals and its use in geological practice. In Occasional Papers of the Geological Institute of Hungary, Vol. 2, 180 p.

Gottman, I. A., E. V. Pushkarev. 2009. Geologicheskie dannye o magmaticheskoi prirode gornblenditov v gabbroul'tramafitovyh kompleksah Uralo-Alyaskinskogo tipa (Geological data on the magma nature of hornblendites in gabbroultramafic complexes of the Ural-Alaskan type). Litosfera, 2, 78-86 (in Russian).

Kobylyanski, A., Zhukova, V., Petrov, G., Boduen, A.Y. 2019. Challenges in processing copper ores containing sulfosalts. DOI: 10.1201/9781003017226-18. In book: Scientific and Practical Studies of Raw Material Issues, pp.120-128.

Lazarenkov, V. G., I. V. Talovina, I. N. Beloglazov, V. I. Volodin. 2006. Platinovye metally $v$ gipergennyh nikelevyh mestorozhdenijah i perspektivy ih promyshlennogo izvlechenija (Platinum metals in supergene nickel deposits and prospects for their commercial extraction). St Petersburg, Nedra, 188 p. (in Russian).

Lvov V., Sishchuk J., Chitalov L. Intensification of Bond ball mill work index test through various methods//17th International multidisciplinary scientific geoconference and expo SGEM - 2017, Vol. 17, Issue 11, pp. 857-864. DOI: 10.5593/sgem2017/11/S04.109. 
Marsh, E., E. Anderson, F. Gray. 2013. Nickel-Cobalt Laterites - A Deposit Model Chapter H of Mineral Deposit Models for Resource Assessment. - In: Scientific Investigations Report 2010-5070-H. Reston, USGS, $38 \mathrm{p}$.

Mikhailov, B. M. 1999. Nickel ores in the Urals. Lithology and Mineral Resources, 35, 4, 351-364.

Mikhailov, B .M. 2002. Perspective of mineral base of nickel industry in Urals. Regionalnaya Geologiya i Metallogeniya, 15, 97-109.

Marin, Y .B., V. G. Lazarenkov. 1992. Magmatic formations and their ore-bearing. St. Petersburg, Mining University (SPbGGI), $166 \mathrm{p}$.

Nikolaeva, E.; Talovina, I.; Duriagina, A.; Vorontcova, N.; Krikun, N. 2019. The main factors influencing of minor intrusions on the formation of nickeliferous weathering crust on the example of the Sakhara and the Elov deposits (Urals). 19th International Multidisciplinary Scientific GeoConference SGEM 2019: SGEM; Sofia Vol. 19, Issue 1.1,: 625-630. Sofia: Surveying Geology \& Mining Ecology Management (SGEM). (2019) DOI:10.5593/sgem2019/1.1/S01.077.

Nikolaeva, E.S., Talovina, I.V., Nikiforova, V.S., Heide, G. 2019. Chemical composition and genesis of serpentinite group minerals in nickeliferous weathering crust of the Elov deposit (Urals). DOI: 10.1201/9781003017226-1. In book: Scientific and Practical Studies of Raw Material Issues, pp.3-10.

Talovina, I. V., G. Heide. 2016. Serpentines of Chrysotile-pecoraite series as genesis indicators of nickel deposits in the Urals weathering crusts. Journal of Mining Institute, 221, 629-637. DOI 10.18454/ PMI.2016.5.629.

Talovina, I. V., V. G. Lazarenkov, S. O. Ryzhkova, V. L. Ugolkov, N. I. Vorontsova. 2008. Garnierite in Nickel Deposits of the Urals. St. Petersburg State Mining Institute (Technical University), Lithology and Mineral Resources, 43, 6, 588-595.

Talovina, I. V. 2012. Geohimija uralskih oksidno-silikatnyh nikelevyh mestorozhdenij (Geochemistry of the Uralian oxide-silicate nickel deposits). St. Petersburg, Natsionalnyi mineralno-syrevoi universitet "Gornyi". 270 p. (in Russian).

Talovina, I. V., N.I. Vorontsova, S. O. Ryzhkova O. P. Mezentseva, A. G. Pilugin. 2012. Harakter raspredelenija redkozemel'nyh jelementov v rudah Elovskogo i Buruktalskogo gipergennyh nikelevyh mestorozhdenij (Pattern of rare earth element distribution in ores of the Elov and Buruktal supergene nickel deposits). Zapiski Gornogo Instituta, 196, 31-35 (in Russian).

Talovina, I. V., V. G.Lazarenkov, N. I. Vorontsova, O. P. Mezentseva, S. O. Ryjkova, A. G. Pilugin. 2010. Geochemistry of impurity elements in Buruktal supergene nickel deposit, South Urals. FreibergSt. Petersburger interdisziplinares Kolloquium junger Wissenschaftler. Technische Universitat Bergakademie Freiberg. 40-43.

Talovina, I.V., V. G. Lazarenkov, U. Kempe, M. Tichomirowa, N. I. Vorontsova, A. G. Pilugin. 2011. Value in Millerite and Genesys of Chamosite Nickel Ores in the Elov Supergene Deposit (Serov Group), North Urals. Scientific Reports on Resource Issues. Vol.1: Latest Developments in Mineral Industry Geology, Mining, Metallurgy and Management. TU Bergakademie Freiberg. 30-34.

Talovina, I. V. 2012. Geochemistry of supergene nickel deposits of the Urals. PhD Thesis, G.-M. Sciences: 25.00.09., St. Petersburg, 270 p.

Volchenko, Y. A., K. S. Ivanov, V. A. Koroteev, T. Auger. 2007. Strukturno-veshhestvennaja evoljuciya kompleksov Platinonosnogo pojasa Urala pri formirovanii hromit-platinovyh mestorozhdenii uralskogo tipa (Structural-compositional evolution of the Ural Platinum Belt complexes during the formation of platinum-chromite deposits of the Ural type). Part 1. - Litosfera, 4, 73-101 (in Russian).

Yudovich, Y. E., M. P. Ketris. 2011. Geochemical indicators of lithogenesis (lithological geochemistry). Syktyvkar, Geoprint, 742 p. 